\title{
Mathematical Modeling of Sun and Solar Drying Kinetics of Fermented Cocoa Beans
}

\author{
Olabinjo O.O. ${ }^{1^{*}}$, Olajide J.O. ${ }^{2}$, Olalusi A .P. ${ }^{1}$ \\ ${ }^{1}$ Department of Agricultural Engineering and Environmental Engineering, Federal University of Technology, Akure. \\ ${ }^{2}$ Department of Food Science and Technology, LadokeAkintola University of Technology, Ogbomoso
}

\begin{abstract}
In this study, thin layer drying experiments were conducted to compute drying characteristics of fermented cocoa beans in open sun and indirect natural convection solar dryer. The drying experiments were conducted at the same time for comparison. Three different thin layers drying of the fermented beans were examined under field conditions for Akure, Nigeria. The drying process took place only in the falling rate period. The drying curves obtained from the experimental data were fitted to thirteen (13) different thin layer mathematical models. All the models were compared according to three evaluation parameters. These include coefficient of determination $\left(R^{2}\right)$, Root mean square error (RMSE) and Chi-square $\left(X^{2}\right)$.The results showed that increasing drying air temperature resulted to shorter drying times. The Vermal et al. model was found to be the most suitable for describing the drying curve of the convective indirect solar drying process of cocoa beans with $R^{2}=0.9562, X^{2}=0.0069$ and $R M S E=0.0067$; while, the Midilli and Kucuk model, best described the drying curve of fermented cocoa beans under open sun with $R^{2}=$ $0.9866, X^{2}=0.0024$ and $R M S E=0.0023$.
\end{abstract}

Keywords - Thin-layer drying, moisture content, modelling,cut test, $\mathrm{pH}$, Cocoa beans.

\section{INTRODUCTION}

Drying is one of the oldest methods of food preservation (Doymaz, 2007). Agricultural and other products have been dried by sun and wind in the open air for thousands of years. The purpose is either to preserve them for later use, as in the case with food; or as an integral part of the production process as with tobacco and cocoa beans. It is necessary that the traditional techniques be replaced with industrial drying methods. (Ertekin and Yaldiz, 2004).

Mathematical modelling and simulation of drying curves under different conditions is important to obtain an overall improvement of the quality of the final product. Simulation models of the drying process are used for developing new designs, improving existing drying systems, predicting the airflow over the product and for the control of the process. (Aghbashlo, et al., 2008). Thin layer drying equations are used to estimate drying kineticsfor several products and also to generalize drying curves.

A critically important aspect of drying technology is mathematical modelling of the drying process. Modelling of drying process and kinetics is a tool for process control and necessary to choose suitable method of drying for specific product. Modelling is also essential for engineers to choose the most suitable climatic conditions in order to design appropriate drying equipment for perishable crops. The aim of this work is to study the drying process and select the most suitable model (in terms of fitting ability) to describe the thin-layer drying of cocoa beans. Although much information has been reported about modelling of thin layer drying (Togrul\&Pehlivan, 2002) there is no information about modelling of thin layer drying of cocoa beans in Nigeria.

\section{MATERIALS AND METHODS}

\subsection{Drying experiments}

In this study, fresh healthy cocoa pods (Amenlonado variety) were procured from Oda village, Akure South Local Government, Akure Ondo State. The drying experiments were carried out using mobile solar dryer in the Department of Agricultural Engineering, Federal University of Technology, Akure. Plate 1 shows the schematic diagram of the solar dryer used for the experimental work which consists of a solar collector and a drying chamber. The samples were weighed using a digital balance with $0.01 \mathrm{~g}$ sensitivity every 60 minutes throughout the drying process.

Three different thin samples of wet fermented cocoa beans were spread evenlyinto the solar dryer and in the open sun drier for the dehydration test. The experiment was replicated thrice and the mean value was used. Thermal drying method was used in the determination of moisture content of the samples.100g of sample were placed in oven at $105 \pm 3{ }^{\circ} \mathrm{C}$ and allowed to dry to a constant weight for 24 hours (Lagha-Benamrouche, S. and Madani, K., 2013). The moisture content (MC) was calculated by expressing the weight loss upon drying a fraction of the initial weight of sample used. The moisture content of the seeds was determined by gravimetric method which determines the mass loss from the sample 
by drying to constant weight (ASABE STANDARDS, 1993 and AOAC, 2000).

$D M(\%)=\frac{W_{3}-W_{0}}{W_{1}-W_{0}} * 100$
$\% M C_{d b}=100-D M \%$

Where $W_{o}$ is weight of empty crucible
$W_{1}$ is weight of crucible plus sample before drying

$W_{3}$ is weight of crucible plus sample after drying

DM is dry matter and $\mathrm{MC}_{\mathrm{db}}$ is the cocoa beans moisture content ( $\mathrm{g}$ water/g dry base, d.b).

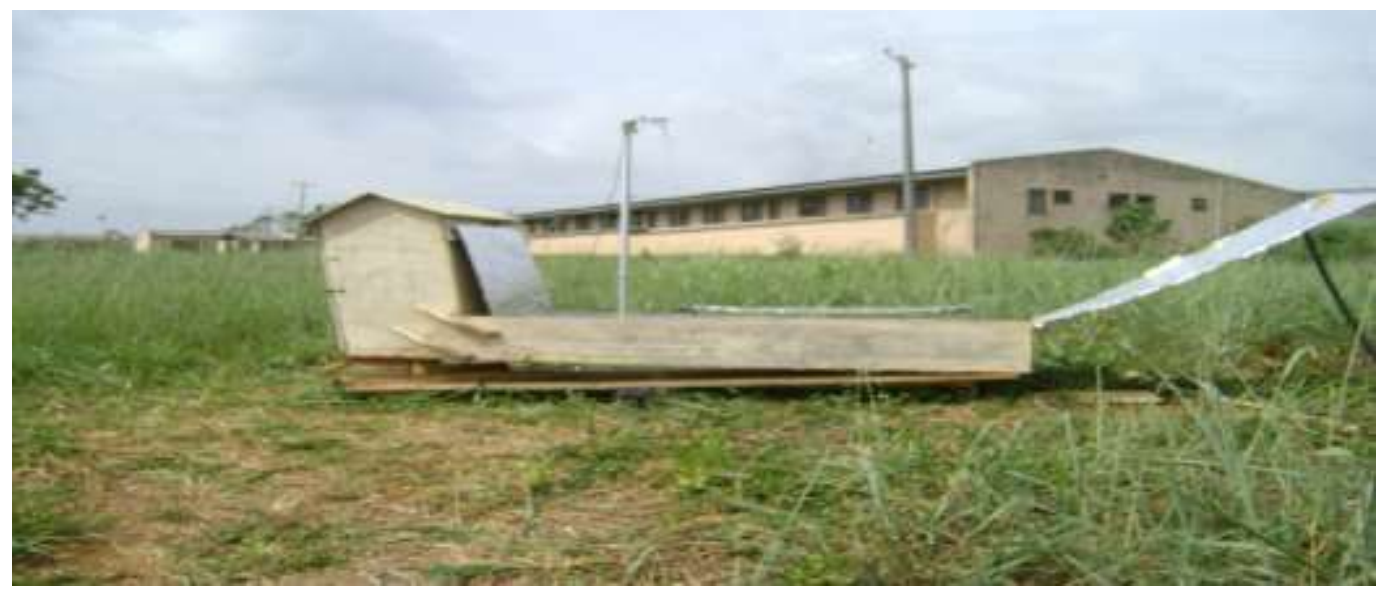

Plate.1: Mobile Solar dryer

2.2 Mathematical modelling of drying process

Many researchers have worked on many thin layer models in the past and this study evaluate thirteen (13) of such models as shown in Table 1.

The moisture ratio, MR is given as follows:

$M R=\frac{M-M_{e}}{M_{o}-M_{e}}$

Where $\mathrm{MR}$ is the dimensionless moisture ratio or unaccomplished moisture content, $\mathrm{M}, \mathrm{M}_{\mathrm{e}}, \mathrm{M}_{\mathrm{o}}$ are moisture content $(\mathrm{kg}$ water $/ \mathrm{kg}$, dry matter) respectively.
The values of $\mathrm{M}_{\mathrm{e}}$ are relatively small compared to those of $\mathrm{M}$ or $\mathrm{M}_{\mathrm{o}}$ hence error involved in its simplification as negligible. (Aghbashlo,Kianmerhrk\&Samini-Akhljahani, 2008), hence moisture ratio is calculated

$M R=\frac{M}{M_{e}}$ or $\frac{M}{M_{o}}$

For drying model selection, drying data were fitted into thirteen well known thin layer drying models which are given in Table 1.

Table.1: Thin layer models used by some researchers and used in evaluating the drying kinetics of Cocoa beans.

\begin{tabular}{|c|c|c|c|}
\hline $\mathbf{S} / \mathbf{N}$ & Model name & Model equation & Refrences \\
\hline 1 & Newton & $\mathrm{MR}=\exp (-\mathrm{kt})$ & Upadhyayet al., 2008 \\
\hline 2 & Page & $\mathrm{MR}=\exp \left(-\mathrm{kt}^{\wedge} \mathrm{n}\right)$ & Saeed et al., (2006) \\
\hline 3 & Modified page & $\mathrm{MR}=\exp \left[-(\mathrm{kt})^{\wedge} \mathrm{n}\right]$ & Ceylanet al., (2007) \\
\hline 4 & Henderson and Pabis & $M R=\operatorname{aexp}(-k t)$ & Kashaninejadand Tabil(2004) \\
\hline 5 & Logarithmic & $M R=\operatorname{aexp}(-k t)+c$ & Wang et al., (2007) \\
\hline 6 & Two-term & $M R=a \exp (-k o t)+b \exp (-k 1 t)$ & Wang et al., (2007) \\
\hline 7 & Two-term exponential & $M R=\operatorname{aexp}\left(-k_{o} t\right) b \exp \left(-k_{1} \mathrm{t}\right)$ & Tariganet al., (2007) \\
\hline 8 & Wang and Singh & $\mathrm{MR}=1+\mathrm{at}+\llbracket \mathrm{bt} \rrbracket \wedge 2$ & Wang and Singh (1978) \\
\hline 9 & Diffusion approach & $\mathrm{MR}=\mathrm{aexp}(-\mathrm{kt})+(1-\mathrm{a}) \exp p_{-}(-\mathrm{kbt})$ & Wang et al., (2007); \\
\hline 10 & $\begin{array}{l}\text { Modified Henderson and } \\
\text { Pabis }\end{array}$ & $M R=a \exp (-k t)+b \exp (-g t)+c \exp (-h t)$ & Kaya et al., (2007b) \\
\hline 11 & Verma et al & $M R=a e x p(-k t(n))+b t$ & Doymaz, (2005b) \\
\hline 12 & Midilli and Kucuk & $M R=\operatorname{aexp}\left(-k t^{n)}+b t\right.$ & Midilliet al., (2002) \\
\hline 13 & Thomson & $\mathrm{t}=\mathrm{a} \ln \mathrm{MR}+\mathrm{b}(\operatorname{In}(\mathrm{MR}))^{\wedge} 2$ & Thomson et al., (1968) \\
\hline
\end{tabular}

Moisture ratio $(\mathrm{MR})=$ dependent variable, Drying constant constant $(\mathrm{k})=$ independent variable.

The goodness of fit was determined using three parameters; coefficient of determination $\left(\mathrm{R}^{2}\right)$, reduced chi-square $\left(\mathrm{x}^{2}\right)$ and the root mean square error (RMSE) using equations (4) - (6) as in Sacilik and Elicin (2008).The statistical analyses were carried out using SPSS 13.0 software and non-regression technique. 
a. Coefficient of determination $\left(\mathrm{R}^{2}\right)$

$$
\begin{aligned}
& R^{2}= \\
& \frac{\sum_{i=1}^{n}(M R i-M R p r e, i) \cdot \sum_{i=1}^{n}(M R i-M R \exp , i)}{\sqrt{\left[\sum_{i=1}^{n}(M R i-M R p r e, i)\right] \cdot \sqrt{ }\left[\sum_{i=1}^{n}(M R i-M R \exp , i)\right]}}
\end{aligned}
$$

Chi-square $\left(x^{2}\right)$

$$
x^{2}=\frac{\sum_{i=1}^{N}\left(M R_{\text {exp. } i}-M R_{\text {pre. } i}\right)^{2}}{N-n}(6)
$$

b. Root mean square error (RMSE)

$$
R M S E=\left[\frac{\sum_{i=1}^{N}\left(M R_{\text {pre. } i}-M R_{\text {exp. } i}\right)^{2}}{N}\right]^{1 / 2}
$$

Where $\mathrm{MR}_{\text {exp, is }}$ ith experimentally observed moisture ratio, $\mathrm{MR}_{\text {pre, is }}$ ith predicted moisture ratio, $\mathrm{N}$ is the number of observation, $\mathrm{n}$ is the number of model constants.

\section{RESULTS AND DISCUSSIONS}

3.1 Drying Kinetics of Fermented cocoa beans

From the experimental data, the moisture content (\%wb) of fermented cocoa beans for the solar dryer and open sun drying at any time are represented in Figures 1-3. It was clearly evident from these curves that the drying rate of fermented cocoa beans in the solar dryer was faster than that of the open sun drying. The moisture content of the fermented cocoa beans reached $6.5 \%$ dry basis in 32 hours of drying in the solar dryer, whereas the final moisture of the same product dried by open sun drying was only $9.87 \%$ dry basis thus moisture content was not enough for safe storage. When it was dried under open sun drying, the duration of dry was about two (2) sunshine days to bring it to the same moisture level.

This can be explained that the main factor influencing drying rate was the drying air temperature. Compared to open sun drying, solar dryer can generate higher air temperature and affected the significant increasing of evaporation rate of water and then result in lower final moisture content of drying samples. These results indicated that solar dryer was effective than open sun drying.

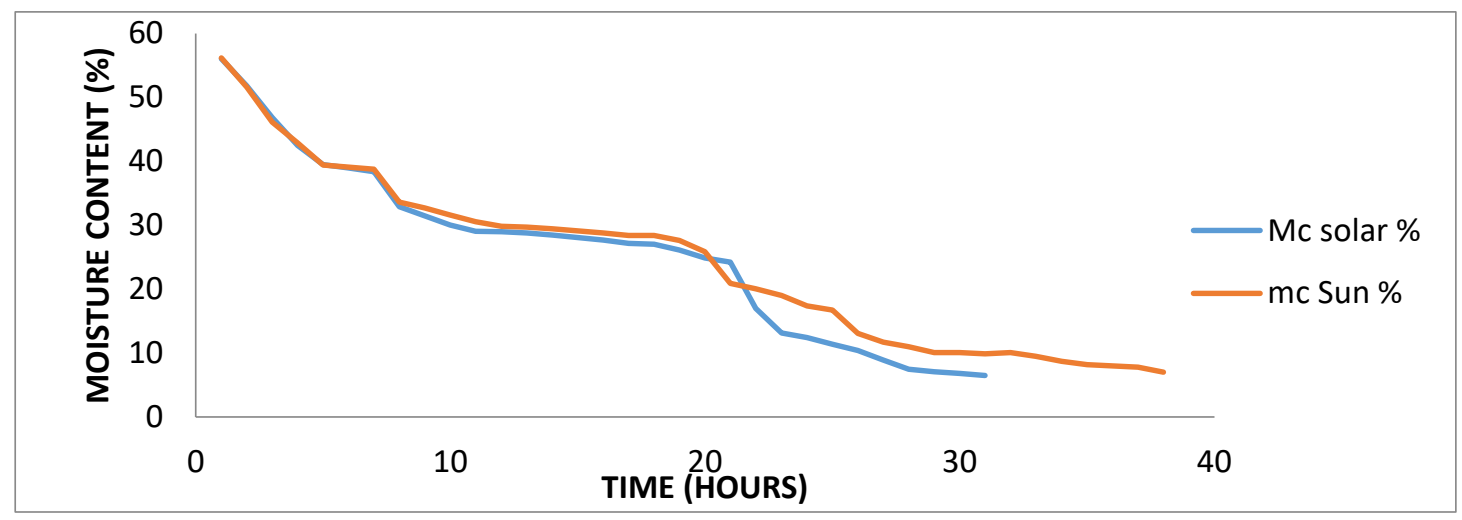

Fig. 1: Variation of moisture content with drying time for fermented cocoa beans for $3.97 \mathrm{~g} / \mathrm{cm}^{2}$

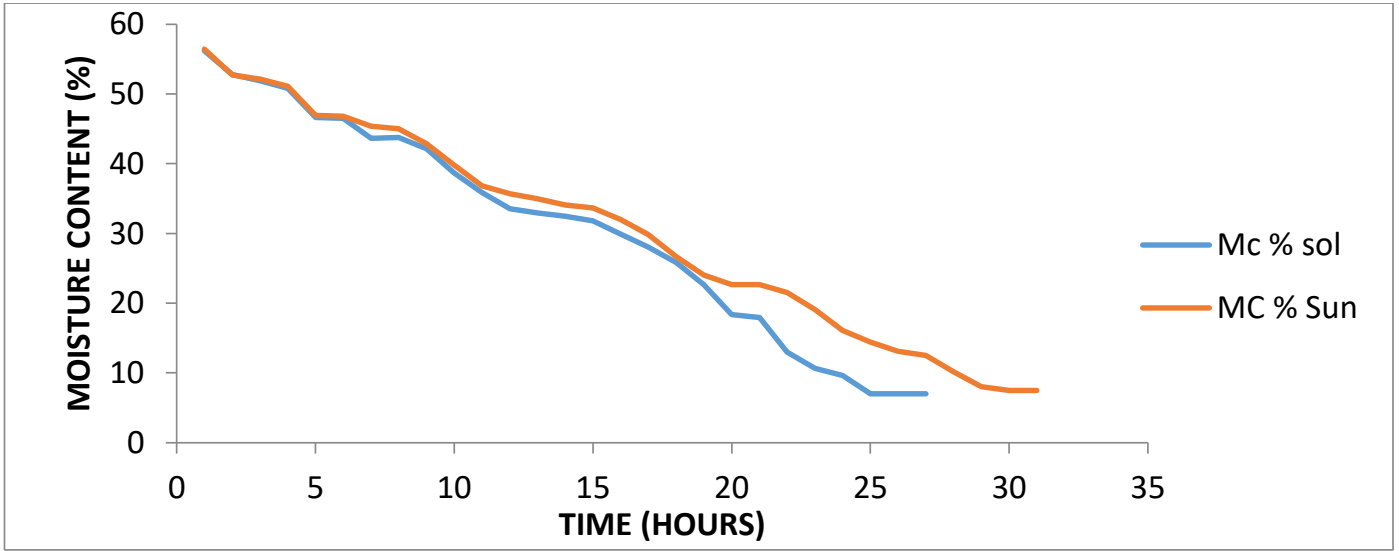

Fig.2: Variation of moisture content with drying time for fermented cocoa beans for $3.21 \mathrm{~g} / \mathrm{cm}^{2}$ 


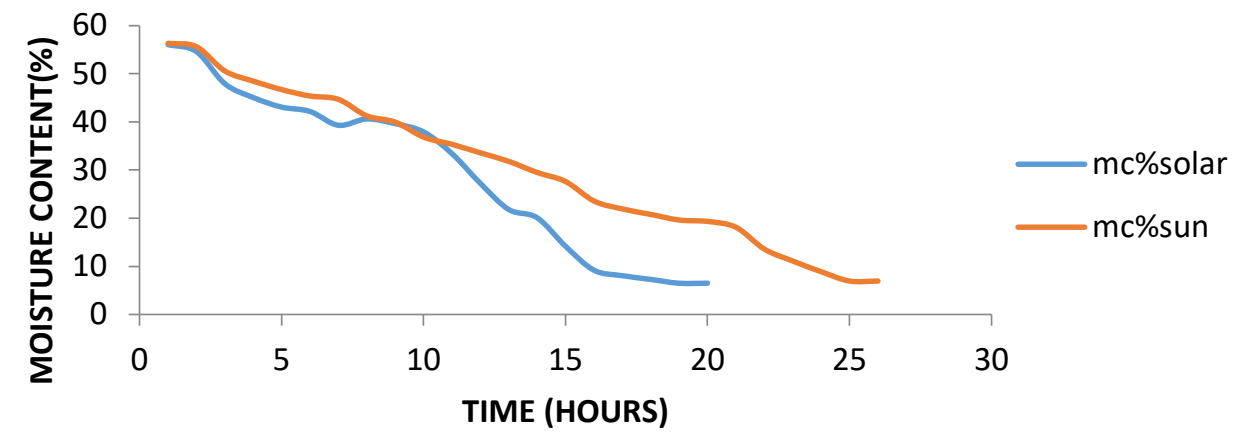

Fig.3: Variation of moisture content with drying time for fermented cocoa beans for $2.97 \mathrm{~g} / \mathrm{cm}^{2}$

\subsection{Mathematical modelling}

The moisture content data at different experimental modes were converted to the more useful moisture ratio expression, and curve fitting computations with drying time were performed with the thirteen (13) drying models presented by previous workers (Table 1).The results of the statistical analyses undertaken on these models for the natural convention solar drying and the natural sun drying are given in Table 2 and 3, respectively. The models were evaluated based on Coefficient of determination $\left(\mathrm{R}^{2}\right)$, Chi-square $\left(x^{2}\right)$, and Root Mean Square Error (RMSE). All equations gave consistently high $(\mathrm{R})$ values in the range of $0.91-0.98$. This indicates that all equations could satisfactorily describe the solar drying rates of fermented cocoa beans. RMSE ranged from 0.0067-1.6465, chisquare ranged from 0.0069-1.1000 and for solar drying while RMSE ranges from 0.0023-1.4672, and chi-square ranges from 0.0024-1.2700 for open sun drying. The result shows that for all thin layer drying models and conditions of solar drying, the Vermaet al. (1985) model gave the best fit with $\mathrm{R}^{2}=0.9562, x^{2}=0.0069$, and $\mathrm{RMSE}=0.0067$ for solar drying . The Midilli model gave the best fit with $\mathrm{R}^{2}=0.9866, x^{2}=0.0024$, and $\mathrm{RMSE}=$ 0.0023 for open sun drying. The drying constants $(\mathrm{k})$ and (1) and coefficients (a) and (n) values as well as the statistical parameters $\mathrm{R}^{2}, x^{2}$, and RMSE are shown in Tables 2 and 3 for both solar drying and open sun drying. Validation of the Vermalet al and Midilli and Kucuk models weremade by comparing the predicted moisture ratio with the experimented moisture ratio values from all the tests. The performance of the Vermalet al model for the thin solar drying and the Midilli and Kucuk model for natural sun drying was illustrated in Figures 4 and 5.The predicted data is banded around the straight line which showed the suitability of the Vermalet al and Midilli and Kucuk models in describing the drying behaviour of fermented cocoa beans in solar and open drying respectively.

Table.2: Modelling the drying process of fermented cocoa beans using solar dryer

\begin{tabular}{|c|c|c|c|c|c|c|}
\hline MODELS & \multicolumn{3}{|c|}{ COEFFICIENT } & \multirow{2}{*}{$\begin{array}{r}\mathbf{R}^{\wedge} \mathbf{2} \\
0.9311\end{array}$} & \multirow{2}{*}{$\begin{array}{r}\mathbf{x}^{\wedge} \mathbf{2} \\
0.0134\end{array}$} & \multirow{2}{*}{$\begin{array}{r}\text { RMSE } \\
0.013\end{array}$} \\
\hline NEWTON & $\mathrm{k}=0.0186$ & & & & & \\
\hline PAGE & $\mathrm{k}=0.0383$ & $\mathrm{n}=0.8255$ & & 0.9351 & 0.0108 & 0.0105 \\
\hline MODIFIED PAGE & $\mathrm{k}=0.0192$ & $\mathrm{n}=0.8255$ & & 0.9351 & 0.0675 & 0.0654 \\
\hline \multicolumn{7}{|l|}{ HENDERSON } \\
\hline \&PABIS & $\mathrm{k}=0.0160$ & $\mathrm{a}=0.8748$ & & 0.9506 & 0.0085 & 0.0082 \\
\hline LOGARITHMIC & $\mathrm{k}=0.0057$ & $a=1.5578$ & $\begin{array}{l}c=-0.7343 \\
a=0.4523\end{array}$ & 0.9662 & 0.0088 & 0.0082 \\
\hline TWO TERM & $\mathrm{ko}=0.0162$ & $\mathrm{k} 1=0.0160$ & $\mathrm{~b}=0.4226$ & 0.9506 & 0.0087 & 0.0081 \\
\hline TWO TERM MOD. & $\mathrm{k}=0.2539$ & $\mathrm{a}=0.0684$ & & 0.9398 & 0.0114 & 0.0107 \\
\hline WANG \&SINGH & $a=-0.0139$ & $b=5.0149$ & & 0.9234 & 1.1 & 106465 \\
\hline $\begin{array}{l}\text { APPRO OF DIF } \\
\text { MOD HENDER }\end{array}$ & \multicolumn{6}{|c|}{ MOD HENDER } \\
\hline$\& \mathrm{PAB}$ & $\begin{array}{l}\mathrm{k}=0.0165 \\
\mathrm{c}=0.3049\end{array}$ & $\begin{array}{l}a=0.2746 \\
g=0.0160\end{array}$ & $\begin{array}{l}\mathrm{b}=0.2954 \\
\mathrm{~h}=0.0158\end{array}$ & 0.9506 & 0.009 & 0.0082 \\
\hline
\end{tabular}




\begin{tabular}{lllllll} 
VERMA ET AL & $\mathbf{k}=\mathbf{1 . 1 4 4 4}$ & $\mathbf{a}=\mathbf{0 . 1 7 0 5}$ & $\mathbf{g}=\mathbf{0 . 0 1 5 2}$ & $\mathbf{0 . 9 5 6 2}$ & $\mathbf{0 . 0 0 6 9}$ & $\mathbf{0 . 0 0 6 7}$ \\
& & & $\mathrm{a}=1.0050$, & & & \\
MIDILLI \& KUCUK & $\mathrm{k}=0.2021$ & $\mathrm{n}=0.1734$ & $\mathrm{~b}=0.0049$ & 0.9787 & 0.4659 & 0.4358 \\
Thompson & $\mathrm{a}=-64.7773$ & $\mathrm{~b}=-8.0810$ & & 0.9655 & 0.8923 & 0.9568 \\
\hline
\end{tabular}

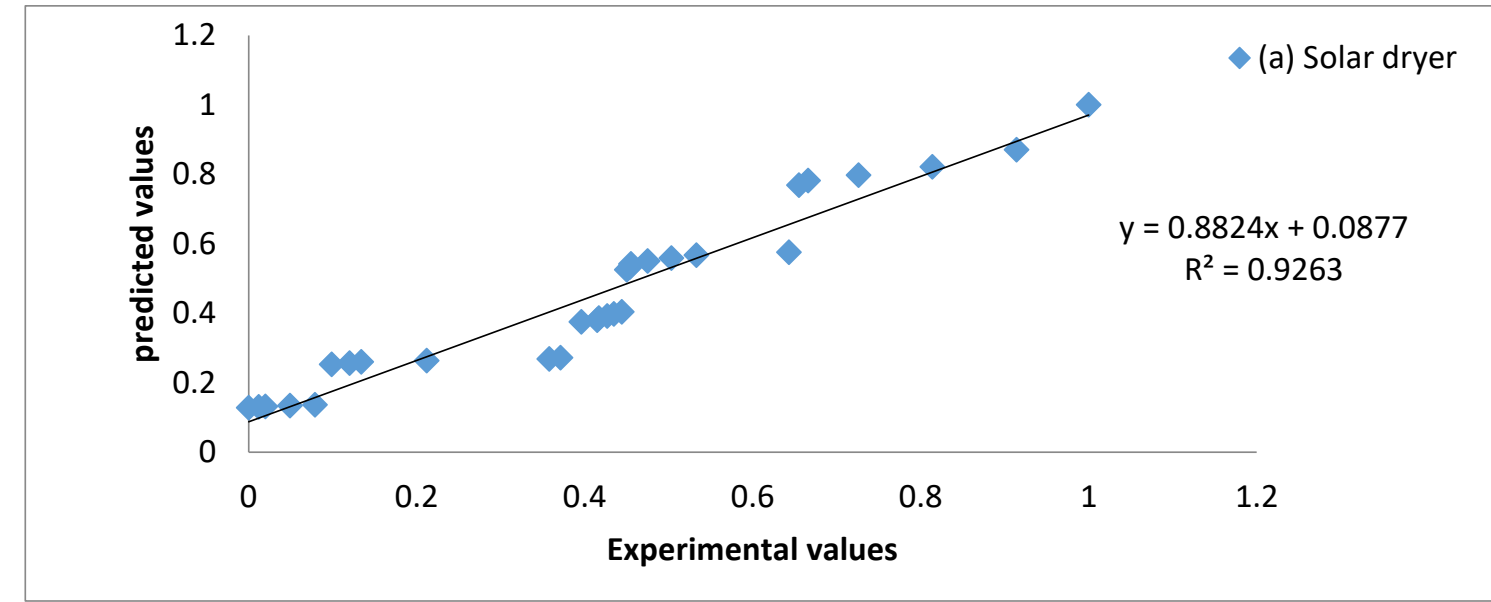

Fig.4: Comparison of experimental and predicted dimensionless moisture ratio for solar drying

Table.3: Modelling the drying process of fermented cocoa beans using open sun drying.

\begin{tabular}{|c|c|c|c|c|c|c|}
\hline MODELS & \multicolumn{3}{|c|}{ COEFFICIENT } & $R^{\wedge} 2$ & $X^{\wedge} 2$ & RMSE \\
\hline NEWTON & \multicolumn{3}{|l|}{$\mathrm{k}=0.0199$} & 0.9423 & 0.0089 & 0.0086 \\
\hline PAGE & \multicolumn{3}{|l|}{$\mathrm{k}=0.0710$} & 0.9617 & 0.0063 & 0.0061 \\
\hline MODIFIED PAGE & \multirow[t]{2}{*}{$\mathrm{k}=0.0217$} & \multicolumn{2}{|l|}{$\mathrm{n}=0.6905$} & 0.9617 & 0.1376 & 0.1339 \\
\hline \multicolumn{6}{|l|}{ HENDERSON } & \\
\hline \&PABIS & $\mathrm{k}=0.0160$ & $\mathrm{a}=0.8334$ & & 0.9741 & 0.0044 & 0.0042 \\
\hline LOGARITHMIC & $\begin{array}{l}\mathrm{k}=0.0125 \\
\text { ko }\end{array}$ & $\mathrm{a}=0.9083$ & $\mathrm{c}=-0.0955$ & 0.977 & 0.0038 & 0.0037 \\
\hline TWO TERM & $=0.0160$ & $\mathrm{k} 1=0.0161$ & $a=0.4507, b=0.3827$ & 0.9741 & 0.0045 & 0.0042 \\
\hline TWO TERM MOD. & $\mathrm{k}=0.1656$ & $\mathrm{a}=0.1071$ & & 0.9572 & 0.007 & 0.0066 \\
\hline WANG \&SINGH & $a=-0.0144$ & $b=5.3256$ & & 0.9149 & 1.27 & 1.1197 \\
\hline APPRO OF DIF & $\mathrm{k}=0.8487$ & $\mathrm{a}=0.2269$ & $b=0.0173$ & 0.9827 & 0.0032 & 0.0031 \\
\hline \multicolumn{7}{|l|}{ MOD HENDER } \\
\hline \multirow[t]{2}{*}{$\& \mathrm{PAB}$} & $\mathrm{k}=0.0159$ & $\mathrm{a}=0.2610$ & $\mathrm{~b}=0.2814$ & 0.9741 & 0.0048 & 0.0042 \\
\hline & $\mathrm{c}=0.2909$ & $\mathrm{~g}=0.0161$ & $\mathrm{~h}=0.0161$ & & & \\
\hline VERMA ET AL & $\mathrm{k}=0.8584$ & $\mathrm{a}=0.0226$ & $\mathrm{~g}=0.0147$ & 0.9827 & 0.0135 & 0.0132 \\
\hline \multicolumn{7}{|l|}{ MIDILLI \& } \\
\hline KUCUK & $k=0.1921$ & $n=0.3235$ & $a=1.0040, b=-0.0023$ & 0.9866 & 0.0024 & 0.0023 \\
\hline THOMPSON & $a=-59.2342$ & $b=-4.0169$ & & 0.9827 & 0.3246 & 1.4672 \\
\hline
\end{tabular}




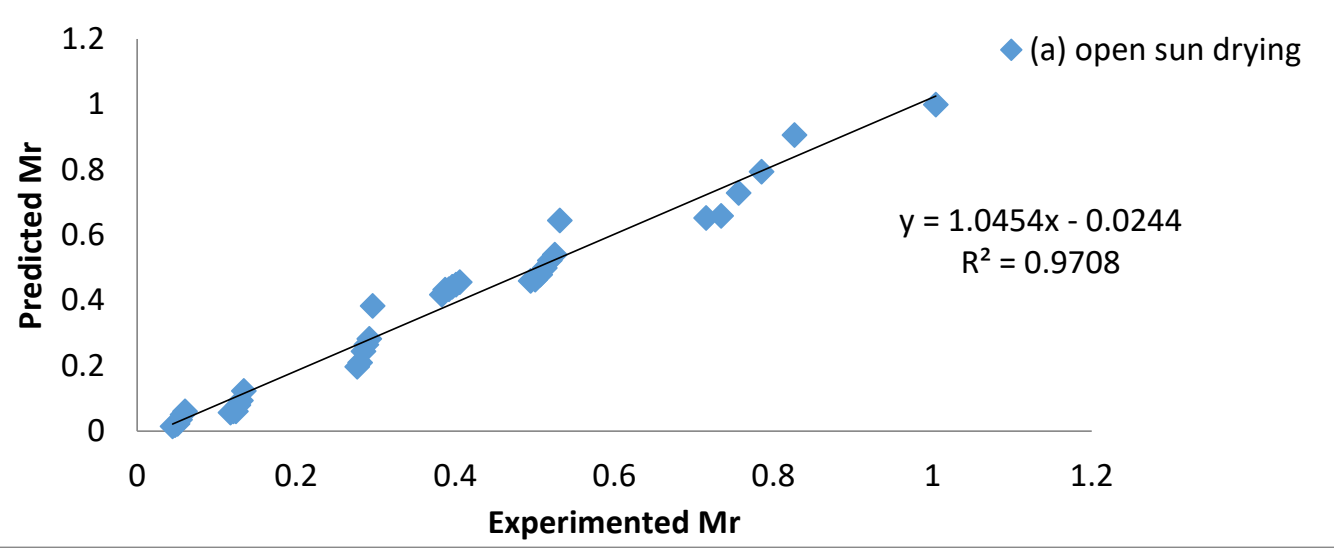

Fig.5: Comparison of experimental and predicted dimensionless moisture ratio for open sun drying

\section{CONCLUSION}

The solar dryer proves useful for local farmer as it ensures high quality, good colour and flavour and reduces the drying time. It does not pollute the environment, requires minimal maintenance once it is installed and with good quality. In order to explain the drying behaviour and the mathematical models of fermented cocoa beans, thirteen models were applied to thin layer convective indirect solar dryer and open drying processes. The result showed that the Vermaet al model was found to be the most suitable model for describing the drying curve of the convective indirect solar drying process of cocoa beans with $\mathrm{R}^{2}$ $=0.9562, x^{2}=0.0068, \mathrm{MBE}=0.0383$ and $\mathrm{RMSE}=0.0067$ while, the Midilli and Kucuk model, best described the drying curve of fermented cocoa beans under open sun with $\mathrm{R}^{2}=0.9866, x^{2}=0.0024, \quad \mathrm{MBE}=0.0078$ and $\mathrm{RMSE}=0.0023$.

\section{REFERENCES}

[1] Aghbasho M., M. H. Kianmehr and H. SamimiAkhljahani (2008).Influence of drying conditions on the effective moisture diffusivity, energy of activation and energy consumption during the thin -layer drying of barberries fruit (Berberidaceae).Energy Conversion and Management,49(10):12865-2871

[2] Anon (1995).Specification for grading of Malaysian cocoa beans ( $3^{\text {rd }}$ revision) SIRIM, Malaysia.

[3] Ayensu, A. (1997). Dehydration of food crops using a solar dryer with convective heat flow. Solar Energy 59:121-126.

[4] Babalis J.S, and Belessiotis G.V (2006). Influence of drying condition on the drying constants and moisture diffusivity during the thin layer drying of figs. Journal of Food Eng., 65: 449- 458

[5] Celma, A.R, S. Rojas, F. Lo'pez, I. Montero and T.Miranda, (2007). Thin-layer drying behavior of sludge of olive oil extraction. Journal of Food Engineering, 80: 1261-1271
[6] Ceylan, I., Aktas, M. and Dog`an, H. (2007). Mathematical modeling of drying characteristics of tropical fruits. Applied Thermal Engineering 27: 1931-1936.

[7] Doymaz,I.(2005).Sundrying of figs: An experimental study. Journal of Food Engineering 71:403-407

[8] Doymaz,I. (2007). Air-drying characteristics of tomatoes. Journal of Food Engineering,78(4) 12911297.

[9] El-Beltagy, A., Gamea G. R., and Amer-Essa A. H. (2007).Solar drying character ristics of strawberry. Journal of Food Engineering 78: 456-464.

[10]ErenturkS.andErenturk. (2007).Drying of eggplant and selection of a suitable thin layer drying model.Journal of Food Engineering,63(3): 349-359.

[11]Ertekin, C., and Yaldiz, O., (2004). Drying of eggplant and selection of a suitable thin layer drying model. Journal of Food Engineering, 63, 349-359

[12]Faborede, M.O and Oladosu, F.A.,(1991). Development of cocoa pod processing machine. The Nigerian Engineer 26(4): 26-31.

[13] Goyal R. K., Kingsly, A. R. P., Manikantan, M. R. and Ilyas, S. M. (2007). Mathematical modelling of thin layer drying kinetics of plum in a tunnel dryer. Journal of Food Engineering 79: 176-180.

[14] Grow cocoa (2004). Global research on cocoa working with and for farmers.

[15]Hii, C. L., Law, C. L., andCloke, M. (2009). Modeling using a new thin layer drying model and product quality of cocoa. Journal of Food Engineering, 90, $191-198$.

[16] Kadlopa,A., and Ngwalo, G.,(2007).Solar dryer with thermal storage and biomass-back up heater. Solar Energy, 81(4):449-462.

[17] Kaleemullah S., and Kailappan R. (2006). Modelling of thin layer drying kinetics of red chillies. Journal of Food Engineering, 76(4): 531-537. 
[18] Karathanos, V.T., (1999). Determination of water content of dried fruits by drying kinetics. Journal of Food Engineering, 39: 337-344.

[19] Kashaninejad, M., and Tabil, L. G. (2004). Drying characteristics of purslane (Portulacaoleraceae L.). Drying Technology, 22, 2183-2200.

[20] Kaya, A., Aydin, O., Demirtas, C. and Akgün, M. (2007). An experimental study on the drying kinetics of quince. Desalination 212: 328-343.

[21] Kingsly, A. R. P.and Singh D. B., (2007).Drying kinetics of pomegranate arils. Journal of Food Engineering, 79:741-744.

[22] Lagha-Benamrouche, S. and Madani, K., (2013). Phenolic contents and antioxidant activity of orange varieties (Citrus sinensisL. and Citrus aurantiumL. cultivated in Algeria: Peels and leaves. Industrial Crops and Products, 50: 723-730.

[23] Lahsasni, S., Kouhila, M., Mahrouz, M. and Jaouhari J. T. (2004b). Drying kinetics of prickly pear fruit (Opuntiaficusindica). Journal of Food Engineering 61: 173-179.

[24] Midilli, A. and Kucuk, H., (2003). Mathematical modeling of thin layer drying of pistachio by using solar energy. Energy Conversion and Management, 44(7):1111-1122.

[25] Midilli, A., H. Kucuk and Z. Yapar, (2002). A new model for single-layer drying. Drying Technology, 20: 1503-1513.

[26] Mustafa, I., Sopian, K. and Daud, W.R.W. (2009). Study of the Drying Kinetics of Lemon Grass. American Journal of Applied Sciences, 1071.

[27] Olalusi, A.P.,(2008). Design, construction and performance evaluation of an indirect solar dryer for shea nut.

[28] Opeke, L.K. (1982). Optimizing economic returns (profit) from cocoa cultivation through efficient use of cocoa by products. Proceeding of $9^{\text {th }}$ International cocoa research conference Lome, Togo, February 1218: 489-493.

[29] Ozdemir, M., and Devres, Y. O. (1999). The thin layer drying characteristics of hazelnuts during roasting. Journal of Food Engineering, 42, 225-233.

[30] Paulsen MR, Thomson TL. (1973). Drying endysus of grain sorghum. Trans ASAE 1973; 16:537-540.

[31] Prachayawarakorn, S., Tia, W., Plyto, N. and Soponronnarit, S. (2008). Drying kinetics and quality attributes of low-fat banana slices dried at high temperature. Journal of Food Engineering, 85:509517.

[32] Rahman M.S, Perera C.O, Theband C. (1998) Desorption isoterm and heat pump drying kinetics of peas. Food Res Int 30:485-91.
[33] Sacilik, K., Keskin, R., and Elicin, A. K. (2006). Mathematical modeling of solar tunnel drying of thin layer organic tomato. Journal of Food Engineering, 73, 231-238.

[34] Saeed,I.E.,Sopian,K., and ZainolAbidin,Z.,(2006). Drying kinetics of Roselle (Hibiscus sabdariffa L.): dried in constant temperature and humidity chamber.Proc.SPS 2006.Edited by Muchtar. 29 ${ }^{\text {th }}$ $30^{\text {th }}$ august.Permata,Bangi,S.D.E.,Malaysia :143-148.

[35] Saeed, I.E, K. Sopian and Z. ZainolAbidin, (2006). Drying kinetics of Roselle (Hibiscus sabdariffa L.): dried in constant temperature and humidity chamber. Proceeding, of SPS 2006. Ed Muchtaret al. 29-30 Aug. Permata, Bangi, Malaysia, 2006, pp: 143-148.

[36] Senadeera W., Bhandari, B. R., Young, G., and Wijesinghe, B. (2003). Influence of shapes of selected vegetable materials on drying kinetics during fluidized bed drying. Journal of Food Engineering, 58, 277-283.

[37] Sogi D. S., Shivhare U. S., Garg S. K., and Bawa, A. S. (2003). Water sorption isotherms and drying characteristics of tomato seeds. Biosystems Engineering, 84, 297-301.

[38] Sunseed Desert Technology (2003). Solar Drying: Drying Food with the energy of the Sun. Retrieved from Url.www.Sunsed.organization.uk.

[39] Tarigan E., Prateepchaikul G., Yamsaengsung R., Sirichote A. and Tekasakul P., (2007). Drying characteristics of unshelled kernels of candle nuts. Journal of Food Engineering, 79: 828-833.

[40] Thomson T.L, Peart P.M, and Foster G.H (1968). Mathematical simulation of corn drying: A new model. Trans ASAE; 11:582-6.

[41] Togrul I. T. and Pehlivan D. (2003). Modeling of drying kinetics of single apricot. Journal of Food Engineering 58:23-32.

[42] Togrul I.T. and Pehlivan D. (2002). Mathematical modeling of solar drying of apricots in thin layer dryers. Journal of Food Engineering 55: 209-216.

[43] Togrul, I.T. and Pehlivan D., (2004). Modeling of thin layer drying kinetics of some fruits under open air sun drying process. Journal of Food Engineering, 65 (3): 413-425.

[44] Upadhyay A.H.K, Sharma, and Sarkar B.C., (2008). "Characterization and Dehydration Kinetics of Carrot Pomace". Agricultural Engineering International: The CIGR Ejournal Manuscript.

[45] Wang C.Y., and Singh R.P., (1978). A single layer drying equation for rough rice. ASAE, paper no. 3001.

[46] Wang, Z, Sun J., Liao X., Chen F., Zhao G., Wu J. and $\mathrm{Hu}$ X., (2007). Mathematical modeling on hot 
air drying of thin layer apple pomace. Food Research International, 40: 39-46

[47] Yaldiz, O. and Ertekyn, C. (2001). Thin layer solar drying of some vegetables. Drying Technology 19(34): 583-597. 